Gut, 1972, 13, 112-123

\title{
Coeliac disease, vasculitis, and cryoglobulinaemia
}

\author{
WILliaM F. DOE, D. EVANS, J. R. HOBBS, AND C. C. BOOTH \\ From the Departments of Medicine, Morbid Anatomy, and Chemical Pathology, Royal Postgraduate \\ Medical School, London
}

SUMMARY Four patients are described with the association of adult coeliac disease, vasculitis, and cryoglobulinaemia. In each patient the cryoglobulinaemia was of the mixed type consisting of more than one immunoglobulin class. It is suggested that the mixed cryoglobulins represent circulating immune complexes and that their deposition in small vessels causes the vasculitis. This is supported by immunofluorescent studies of skin biopsies from one of these patients. The significance of these findings in the four adult coeliac patients is discussed.

There is increasing evidence implicating immune mechanisms in the pathogenesis of coeliac disease (Taylor, Truelove, Thomson, and Wright, 1961; Rubin, Fauci, Sleisenger, and Jefferies, 1965; Katz, Kantor, and Herskovic, 1968; Hobbs and Hepner, 1968; Booth, 1970; Soltoft, 1970). In recent years we have seen four patients with adult coeliac disease, vasculitis, and a mixed cryoglobulinaemia. Such an association prompts further speculation on the immunological mystery of coeliac disease. This paper describes the clinical, biochemical, and immunological features of the four patients with this hitherto unreported association.

\section{Materials and Methods}

CR YOGLOBULINS

These were isolated and purified by centrifugation from serum separated at $37^{\circ}$ and preserved for 12 hours at $4^{\circ}$. The precipitate was then resuspended in cold buffered saline, washed four times at $4^{\circ}$, and finally resuspended in phosphate-buffered saline. To avoid losses from the small amounts of serum available from two patients (cases 3 and 4) only one precipitation and resuspension cycle was performed. Immunoglobulin concentrations were measured by a modified Mancini plate technique (Mancini, Carbonara, and Heremans, 1965) on serum at $37^{\circ}$ and then again on the supernatant at $4^{\circ}$ after cryoprecipitation had occurred. In two patients (cases 3 and 4) these estimations were carried out at $20^{\circ}$ and at $4^{\circ}$ respectively. To characterize further the nature of the cryoglobulins, double diffusion in agar gel (Ouchterlony, 1958) and immunoelectrophoresis were performed.

Received for publication 2 November 1971.
SERUM C $C_{3}$ LEVELS

Serum $\mathrm{C}_{3}$ levels were measured by a Mancini plate technique using goat antihuman $\mathrm{C}_{3}$ (Hyland Laboratories). The levels in 20 healthy control subjects ranged from 100 to $200 \mathrm{mg} / 100 \mathrm{ml}$.

\section{HAEMOLYTIC COMPLEMENT}

Total haemolytic complement was measured by the method of Mayer, Croft, and Gray (1948). Crossed immunoelectrophoresis (Laurell, 1965) was used for the detection of degradation products of complement $\left(\mathrm{C}_{3}\right)$ in fresh serum from two patients (cases 1 and 2).

ANTISERA TO HUMAN IgG, IgA, and IgM These antisera were prepared by injection of pooled myeloma sera with Freund's complete adjuvant into rabbits. Antiserum to the $\mathrm{C}_{3}$ component of complement was similarly prepared in rabbits from normal human sera. Antihuman fibrinogen (Hyland Laboratories) and fluorescein (FITC) conjugated rabbit antihuman IgG, IgA, and IgM (Nordic Laboratories), and rabbit antihuman gamma globulin (Burroughs Wellcome) were used for the immunofluorescent studies.

\section{SKIN BIOPSY}

Skin biopsies were performed under local anaesthesia and frozen sections $5 \mu$ thick were prepared using a cryostat.

\section{GEL FILTRATION}

Sephadex gel filtration was carried out using G200 in a glass column $2.5 \times 100 \mathrm{~cm}$, bed volume $485 \mathrm{ml}$, with downward flow elution using $0 \cdot 2 \mathrm{M}$ glycine/ $\mathrm{HCl}$ buffer, $p \mathrm{H} 3 \cdot 2$, at a flow rate of $0 \cdot 3 \mathrm{ml}$ per minute. 
Three $\mathrm{ml}$ fractions were examined at $280 \mathrm{~m} \mu$ using an Hitachi Perkins-Elmer spectrophotometer.

\section{LATEX FIXATION}

This test was performed according to the method of Singer and Plotz (1956).

\section{SHEEP CELL AGGLUTINATION TEST}

This was performed according to the technique of Rose, Ragan, Pearce, and Lipman (1948).

\section{Patients}

Case reports of the four patients are detailed below and are summarized in Table $I$.

\section{CASE 1: ADULT COELIAC DISEASE, CRYOGLOBU-} LINAEMIA, AND VASCULITIS

V.A. attended Hammersmith Hospital in 1955 at the age of 42 with symptoms of anaemia (haemoglobin $6.6 \mathrm{~g} / 100 \mathrm{ml}$ ), Raynaud's phenomenon, arthralgia of the knees, ankles, and fingers, and transient subcutaneous swellings on the forearms and hands. There was a blotchy, erythematous, papular rash which appeared periodically, lasting two to three days, and confined to the buttocks and lower limbs. The rash was precipitated by standing or prolonged exercise but was unaffected by cold. The rash subsided spontaneously and the anaemia responded to treatment with oral iron. He remained well until 1965, when both the skin rash and the anaemia recurred. Clinical examination now revealed a tall, pale man with an erythematous papular rash confined to the buttocks and lower limbs (Fig. 1).

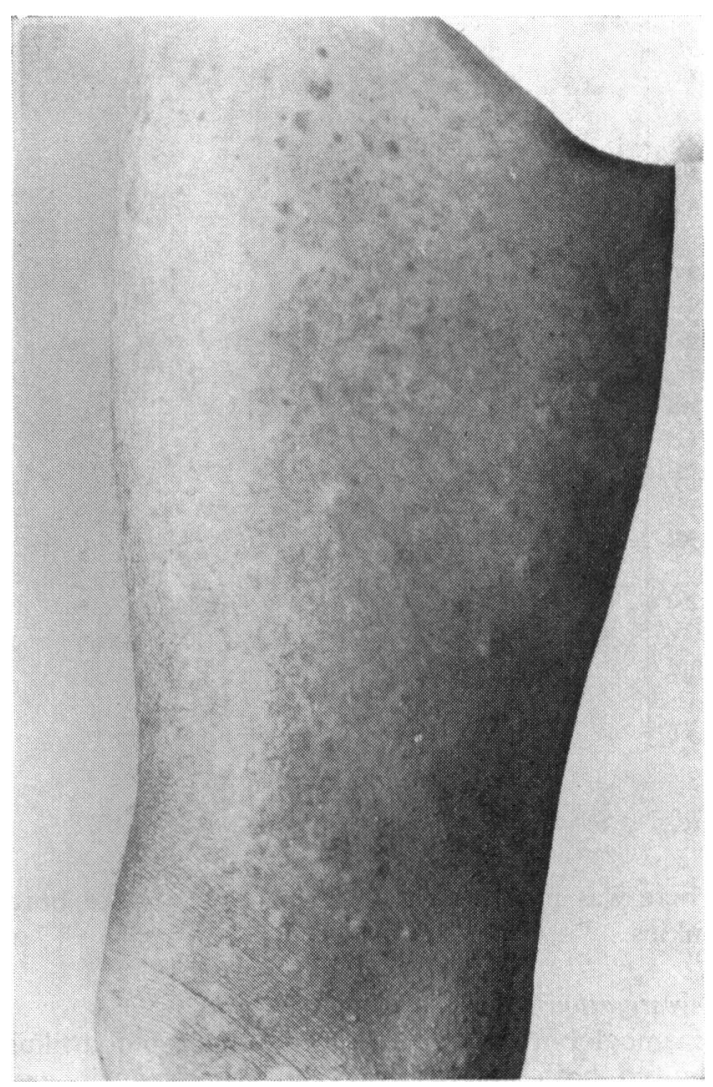

Fig. 1 Blotchy, papular rash seen on the thigh of case 1 .

\begin{tabular}{|c|c|c|c|c|c|c|}
\hline \multirow[t]{2}{*}{ Patient } & \multicolumn{4}{|c|}{ Clinical Data when Coeliac Disease Diagnosed } & \multirow{2}{*}{$\begin{array}{l}\text { Cryoglobulinaemia } \\
\text { Features }\end{array}$} & \multirow[t]{2}{*}{ Course and Complications } \\
\hline & Jejunal Biopsy & $\begin{array}{l}\text { Faecal Fat } \\
(\mathrm{g} / 24 \mathrm{hr})\end{array}$ & $\begin{array}{l}\text { Haemoglobin } \\
(\mathrm{g} / 100 \mathrm{ml})\end{array}$ & $\begin{array}{l}\text { Serum Folate } \\
(\mathrm{ng} / \mathrm{ml})\end{array}$ & & \\
\hline $\begin{array}{l}\text { Case } 1 \\
\text { M54(VA) }\end{array}$ & $\begin{array}{l}\text { Subtotal villous } \\
\text { atrophy }\end{array}$ & $13 \cdot 5$ & 8.0 & $1 \cdot 0$ & \multirow{4}{*}{$\begin{array}{l}\text { Dermal vasculitis } \\
\text { Raynaud's, arthralgia, } \\
\text { lymphadenopathy } \\
\text { ?Erythema nodosum, } \\
\text { retinal haemorrhage, } \\
\text { retinal periphlebitis, deep } \\
\text { venous thromboses } \\
\text { Erythema nodosum, } \\
\text { dermal vasculitis }\end{array}$} & \multirow{2}{*}{$\begin{array}{l}\text { Rash and coeliac disease responded to } \\
\text { steroids; well on GFD }{ }^{2} \text { but rash returned } \\
\text { when steroids ceased } \\
\text { Sarcoidosis, positive thyroid and gastric } \\
\text { antibodies; good response to GFD; } \\
\text { well on maintenance steroids and GFD }\end{array}$} \\
\hline $\begin{array}{l}\text { Case 2 } \\
\text { F38(MC) }\end{array}$ & $\begin{array}{l}\text { Subtotal villous } \\
\text { atrophy }\end{array}$ & 28 & $10 \cdot 8$ & $2 \cdot 0$ & & \\
\hline $\begin{array}{l}\text { Case } 3 \\
\text { F67(EB) }\end{array}$ & $\begin{array}{l}\text { Subtotal villous } \\
\text { atrophy }\end{array}$ & 25 & $13 \cdot 1$ & $10 \cdot 1^{1}$ & & $\begin{array}{l}\text { Good initial response to GFD; } \\
\text { deteriorated after gluten challenge; rash } \\
\text { developed, unresponsive to steroids; } \\
\text { Addison's disease; no autoantibodies; } \\
\text { died with perforated gastric ulcers }\end{array}$ \\
\hline $\begin{array}{l}\text { Case } 4 \\
\text { M50(HS) }\end{array}$ & $\begin{array}{l}\text { Partial villous } \\
\text { atrophy }\end{array}$ & $14 \cdot 3$ & $7 \cdot 0$ & $1 \cdot 5$ & & $\begin{array}{l}\text { Good initial response to GFD; } \\
\text { later, following gluten challenge, coeliac } \\
\text { disease and rash unresponsive to steroids; } \\
\text { died with septicaemia }\end{array}$ \\
\hline
\end{tabular}

Table Clinical summaries of four patients

1 Patient taking regular folic acid supplements.

'GFD = gluten-free diet.

'Biopsy taken after 10 years' treatment with a gluten-free diet. 


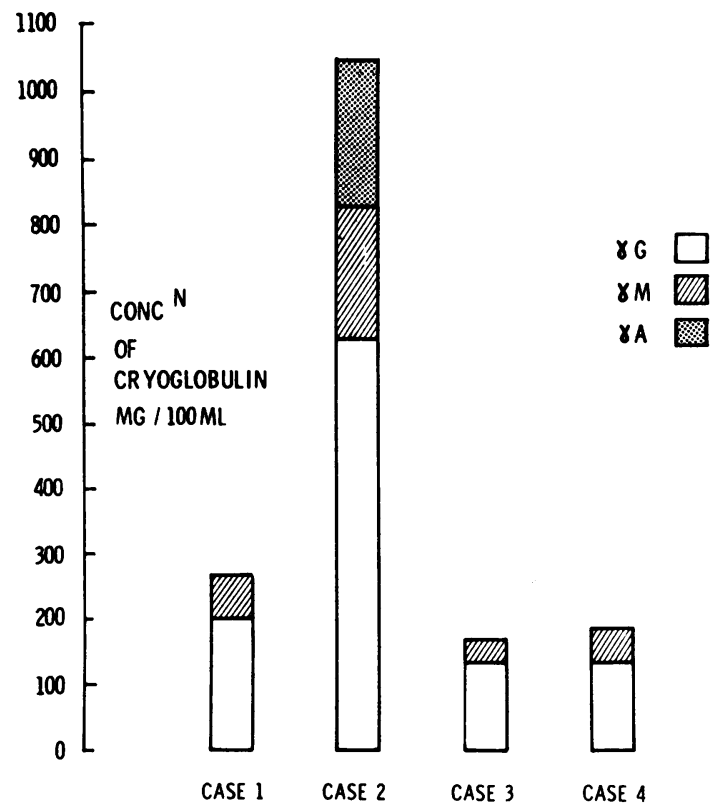

Fig. 2 Serum cryoglobulin concentrations.

There was pigmentation and purpura around both ankles.

\section{Investigations}

Haemoglobin was $8.0 \mathrm{~g} / 100 \mathrm{ml}$. Stained blood films showed both microcytosis and macrocytosis and the bone marrow revealed mild megaloblastic changes with marked iron deficiency. Serum folate was markedly reduced $(1.0 \mathrm{ng} / \mathrm{ml})$ but serum $B_{12}$ was normal $(310 \mathrm{pg} / \mathrm{ml})$.

Intestinal function tests showed a flat glucose tolerance test, the blood glucose rising only to 105 $\mathrm{mg} / 100 \mathrm{ml}$ from a fasting level of $80 \mathrm{mg} / 100 \mathrm{ml}$ one and a half hours after $50 \mathrm{~g}$ of oral glucose. D-Xylose excretion was $2.9 \mathrm{~g}$ in five hours after an oral load of $25 \mathrm{~g}$ (normal $5 \mathrm{~g}$ /five hours). The daily faecal fat excretion during two successive three-day balances averaged $13.5 \mathrm{~g}$. Jejunal biopsy suggested the diagnosis of adult coeliac disease since on dissecting microscopy the appearance was flat, and on histology there was subtotal villous atrophy.

\section{Treatment and progress}

Despite a satisfactory haematological response to treatment with oral iron (ferrous sulphate $300 \mathrm{mg}$, three times daily) and folic acid (5 mg three times daily), the rash became progressively more extensive and by October 1967 involved the forearms as well as the buttocks and lower limbs. In addition, there was a marked lymphadenopathy of the axillary, superficial inguinal, and femoral regions. A skin biopsy now revealed vasculitis. There was perivascular oedema and a marked infiltration with lymphocytes, plasma cells, and polymorphonuclear leucocytes. The lymph node biopsy, however, showed the non-specific appearances of reactive hyperplasia. Cryoglobulins were now detected in the serum.

\section{Immunological studies}

The cryoglobulin concentration was $260 \mathrm{mg} / 100 \mathrm{ml}$ and consisted of mixed $\mathrm{IgG}(200 \mathrm{mg} / 100 \mathrm{ml})$ and IgM $(60 \mathrm{mg} / 100 \mathrm{ml})$ components (Fig. 2). This was confirmed using double diffusion in agar gel but no lines of precipitation formed against antisera to the $\mathrm{C}_{3}$ component of complement or to fibrinogen. When immunoelectrophoresis of the isolated cryoprotein was performed, the broad lgG arc suggested that this cryoglobulin component was polyclonal (Fig. 3). The electrophoretic strip of serum proteins showed an increase in the serum globulins $(3.4$ $\mathrm{g} / 100 \mathrm{ml}$ ) but there was no evidence of a paraprotein and examination of concentrated urine did not reveal any Bence Jones protein. There was a marked increase in the ESR when measured at $37^{\circ}$ (50 $\mathrm{mm}$ in the first hour) and compared to the ESR at $15^{\circ}$ ( $24 \mathrm{~mm}$ in the first hour). The purified cryoglobulin retained its cryoprecipitability after being heated at $56^{\circ}$ for 30 minutes.

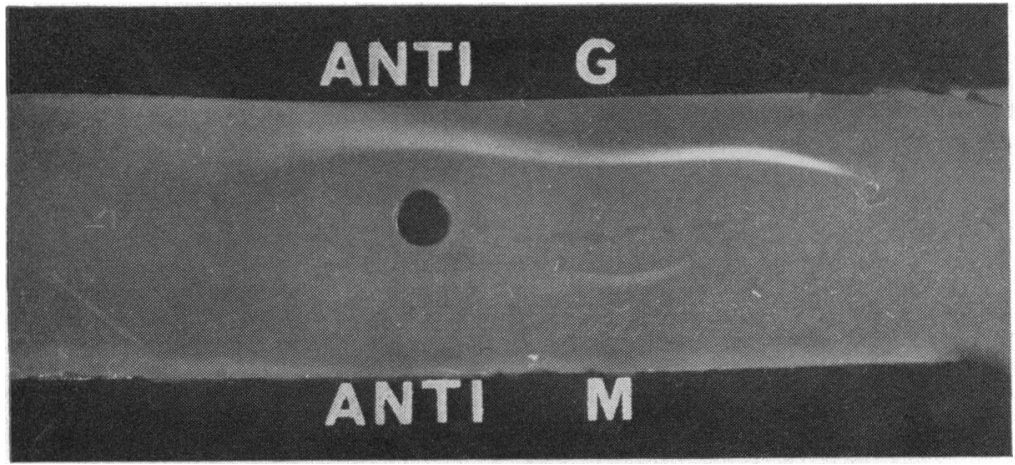

Fig. 3 Immunoelectrophoresis of the cryoprecipitate from case 1 (in the well) against specific anti IgG and IgM antisera. The broad $\operatorname{Ig} G$ arc suggests that this cryoglobulin component is polyclonal. 


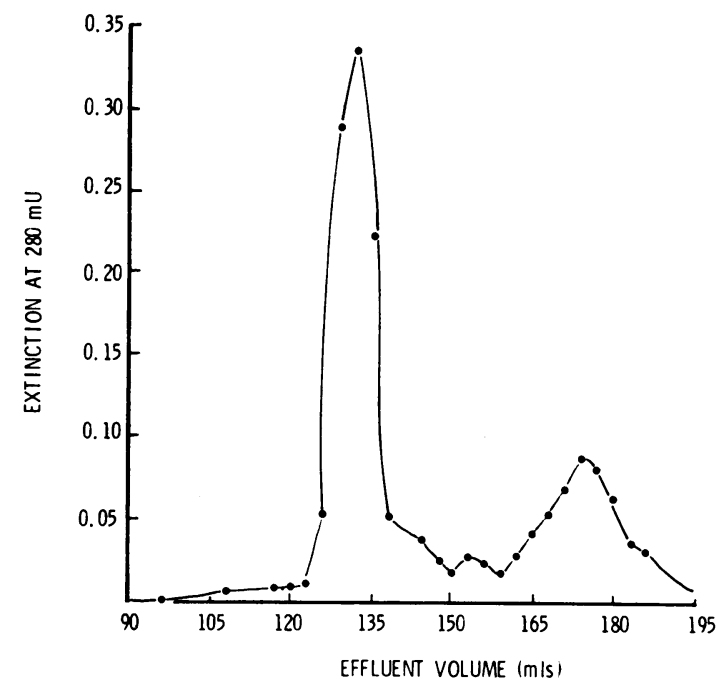

Fig. 4 Separation of the cryoprecipitate from case 1 using Sephadex G200 gel filtration into its IgM (first peak) and $\operatorname{Ig} G$ (second peak) components.

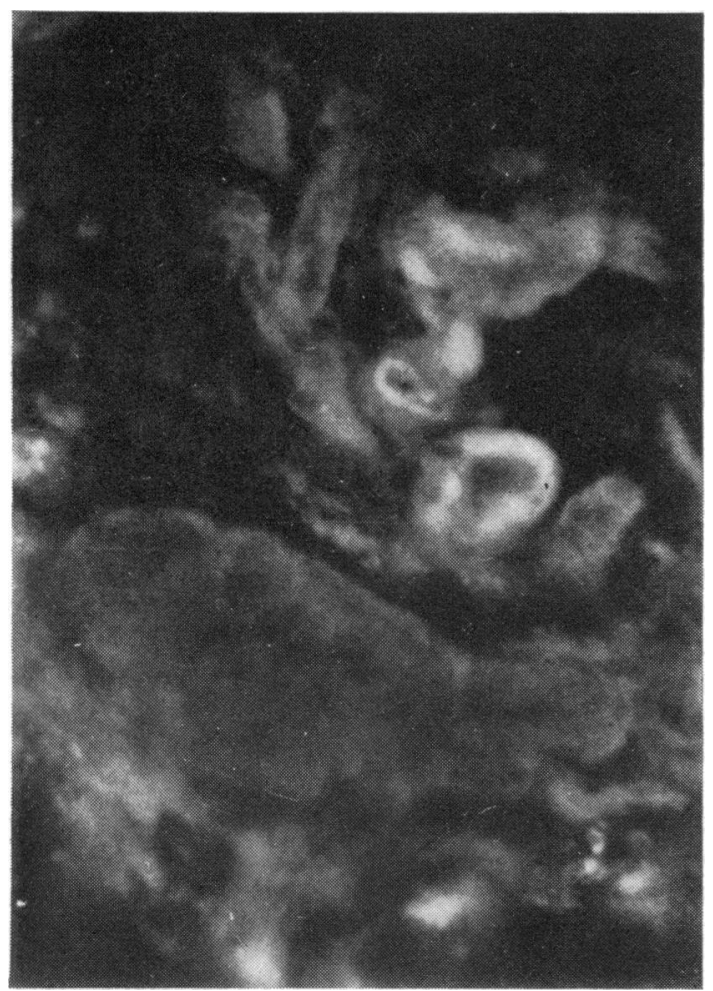

Fig. 5 Section of skin biopsy from case 1 showing positive fluorescence around dermal vessels after staining with fluorescein-conjugated anti $\mathbf{I g G}$.
The cryoprotein was then separated into its pure IgM and IgG components using a Sephadex G200 column and glycine $/ \mathrm{HCl}$ buffer to dissociate the complexes. Two clearly defined peaks were obtained (Fig. 4), corresponding to IgM and IgG. Neither of these fractions alone behaved as a cryoprotein even after concentration 10 times. However, when the IgM and the IgG fractions were mixed, a cryoprecipitate formed at $4^{\circ}$ which readily redissolved on warming to $37^{\circ}$. The IgG fraction was shown to consist of both kappa and lambda light chain types, confirming that this fraction was polyclonal. In the lgM fraction, however, only kappa light chains were found, showing that this fraction was monoclonal. No antibody activity was found against $a$ gliadin (Hekkens, Haex, and Willighagen, 1970) or against crude gliadin (BDH) in either the IgG or the IgM fractions, when tested using double diffusion in agar gel.

Serum $C_{3}$ concentration $(119 \mathrm{mg} / 100 \mathrm{ml})$ and total haemolytic complement estimations were within normal limits. No degradation products of $\mathrm{C}_{3}$ were found in fresh serum. The direct antiglobulin test was positive to 1 in 256 dilution and the latex test was also positive but no cold agglutinins or LE cells were detected.

Using specific antisera conjugated with fluorescein (FITC), frozen sections of skin biopsies of the rash taken at different stages of the lesions were examined by fluorescent microscopy. Deposition of JgG (Fig. 5), IgM, and fibrinogen was demonstrated around dermal vessels but there was no fluorescence when antiserum to the $C_{3}$ component of complement was used.

\section{Further treatment and progress}

After treatment with prednisone $(40 \mathrm{mg} / \mathrm{day})$, the skin rash disappeared but recurred if the dose was reduced to below $10 \mathrm{mg} / \mathrm{day}$. Prednisone was then stopped and a strict gluten-free diet given. This resulted in marked improvement in the absorption function tests and return of the jejunal mucosa towards normal appearances, confirming the diagnosis of adult coeliac disease. The patient remains well in full-time employment on treatment with a glutenfree diet. The skin rash, however, persists.

CASE 2: ADULT COELIAC DISEASE, SAR COIDOSIS, AND CRYOGLOBULINAEMIA

M.C. was 31 when she developed acute sarcoidosis in 1963. There was fever, erythema nodosum, bilateral anterior uveitis, polyarthritis, and generalized lymphadenopathy. Chest radiographs revealed bilateral hilar lymphadenopathy and extensive pulmonary mottling. A Mantoux test was negative at 1 in 100, a conjunctival biopsy showed 
non-caseating granulomata, and subsequently the Kveim test was positive. She was treated with systemic prednisolone $(30 \mathrm{mg} /$ day $)$ and betamethasone eye drops. In February 1964, however, while still on prednisolone $(10 \mathrm{mg} /$ day $)$ she developed retinal periphlebitis with haemorrhages and partial central retinal vein occlusion. The right popliteal region became painful and tender, suggesting thrombophlebitis. Despite gradual resolution of her eye condition following anticoagulant therapy and increased prednisolone $(40 \mathrm{mg} /$ day $)$, her weight did not increase. Diarrhoea and abdominal pain developed, and further investigations were therefore carried out in March 1965. Clinical examination at this time revealed a pale, thin woman with koiloonychia. There was no lymphadenopathy or splenomegaly.

\section{Investigations}

Haemoglobin was $11.6 \mathrm{~g} / 100 \mathrm{ml}$. A stained blood film revealed hypochromia and bone marrow showed megaloblastic changes with iron deficiency. Serum folate was markedly reduced $(2 \mathrm{ng} / \mathrm{ml})$, and both serum $B_{12}(125 \mathrm{pg} / \mathrm{ml})$ and iron $(37 \mu \mathrm{g} / 100 \mathrm{ml})$ were low.

Intestinal function tests showed a markedly reduced $D$ xylose absorption $(0.3 \mathrm{~g}$ excreted in five hours after an oral load of $25 \mathrm{~g}$ ), an increased daily faecal fat excretion ( $28 \mathrm{~g} /$ day $)$, and the Schilling test was abnormal, only $0.4 \%$ of the oral test dose given with intrinsic factor being excreted in 24 hours. Jejunal biopsy showed subtotal villous atrophy.

\section{Treatment and progress}

There was a rapid clinical response following treatment with a strict gluten-free diet and folic acid, vitamin $\mathbf{B}_{12}$, and iron supplements. The weight increased and diarrhoea ceased. In August 1965, five months after oral prednisolone was ceased, deep venous thrombosis of the right leg developed. Resolution of the thrombosis followed a further course of anticoagulants. Chest radiographs now showed a considerable increase in pulmonary mottling and prednisolone therapy $(15 \mathrm{mg} /$ day maintenance) was therefore reintroduced. She remained well, apart from an attack of herpes zoster in August 1967, until further weight loss and deep venous thrombosis recurred in September 1968. Cryoglobulins were now detected in the serum.

\section{Immunological studies}

The total cryoglobulin concentration in the serum was $1,090 \mathrm{mg} / 100 \mathrm{ml}$; the IgG component was 675 $\mathrm{mg} / 100 \mathrm{ml}, \mathrm{IgA} 215 \mathrm{mg} / 100 \mathrm{ml}$, and IgM $200 \mathrm{mg} / 100$ $\mathrm{ml}$ (Fig. 2). There was a marked increase in the serum globulins $(4.8 \mathrm{~g} / 100 \mathrm{ml})$, predominantly due to alpha 2 and gamma globulins but there was no evidence of a paraprotein. Both thyroid and gastric parietal cell autoantibodies were found in the serum (thyroglobulin tanned red cell agglutination titre 1 in 640, colloid and thyroid cytoplasmic antibodies positive) but tests for antinuclear factor and intrinsic factor antibodies were negative. The serum $\mathrm{C}_{3}$ level was increased $(255 \mathrm{mg} / 100 \mathrm{ml})$ but the estimation of total haemolytic complement was normal.

\section{Further treatment and progress}

Following resolution of the deep venous thrombosis, the patient remains well on a gluten-free diet, but still requires systemic prednisolone $(10 \mathrm{mg} /$ day $)$ for her pulmonary sarcoidosis.

CASE 3: ADULT COELIAC DISEASE, CRYOGLOBULINAEMIA, VASCULITIS, AND ADDISON'S DISEASE

E.B. was a 67-year-old woman at the time of her death in 1967. She suffered episodes of diarrhoea during her childhood and at the age of 37 developed a macrocytic anaemia which responded to treatment with parenteral crude liver extract. Some years later, parenteral vitamin $B_{12}$ was substituted for the crude liver extract, and the anaemia recurred. At the age of 41, tender, raised, reddish-purple nodules appeared on the lower legs, lasting for about three months, and then subsiding spontaneously. Ten years later, left radical mastectomy was carried out for carcinoma of the breast, followed by a course of radiotherapy. The patient remained well until 1965, when she lost weight and developed severe diarrhoea and paraesthesiae of the hands. She was then admitted to Hammersmith Hospital. Clinical examination at this time revealed a wasted, elderly woman with marked carpopedal spasm.

\section{Investigations}

Haemoglobin was $13 \cdot 1 \mathrm{~g} / 100 \mathrm{ml}$. Stained blood films showed slight hypochromasia and occasional hypersegmented polymorphs but the bone marrow was normal. Serum folate $(10 \cdot 1 \mathrm{ng} / \mathrm{ml})$ and $B_{12}(250$ $\mathrm{pg} / \mathrm{ml}$ ) were normal but the serum iron was low $(80 \mu \mathrm{g} / 100 \mathrm{ml})$. There was a reduced serum albumin $(2.8 \mathrm{~g} / 100 \mathrm{ml})$, subnormal serum calcium $(3.8 \mathrm{mN})$, and a low serum inorganic phosphate $(1.3 \mathrm{mN})$. Serum alkaline phosphatase was normal (12 KAU). Bone biopsy showed severe osteomalacia and there was no detectable vitamin D-like activity in the serum on bioassay (Melvin, Hepner, Bordier, Neale, and Joplin, 1970).

Intestinal function tests showed a normal glucose tolerance but D-xylose excretion was reduced, $2 \cdot 1 \mathrm{~g}$ of a $25-\mathrm{g}$ load being excreted in five hours. Faecal fat excretion averaged $25 \mathrm{~g}$ daily on a $70-\mathrm{g}$ fat intake 
and the Schilling test was markedly abnormal, only $0.3 \%$ of the oral test dose given with intrinsic factor being excreted in 24 hours. Jejunal biopsy showed a completely flat mucosal surface on dissecting microscopy and subtotal villous atrophy on histology section.

\section{Treatment and progress}

There was a good initial clinical response to a glutenfree diet. Her weight increased and the stools returned to normal, further faecal fat estimations showing only $3.6 \mathrm{~g} /$ day (Fig. 6). Four months after commencing the diet, however, papular erythematous non-tender lesions, $1-3 \mathrm{~cm}$ in size, appeared on the neck, trunk, and lower limbs, fading to leave pigmented areas.

\section{Immunological studies}

Serum taken after the onset of the rash showed a cryoglobulin concentration of $170 \mathrm{mg} / 100 \mathrm{ml}$ consisting of mixed IgG $(135 \mathrm{mg} / 100 \mathrm{ml})$ and $\mathrm{IgM}$ $(35 \mathrm{mg} / 100 \mathrm{ml}$ ) components (Fig. 2) and the direct antiglobulin test was strongly positive. The electrophoretic strip of serum proteins showed a nonspecific increase in alpha 1 and alpha 2 bands and increased gamma globulins but no evidence of a paraprotein. There was no evidence of serum adrenal, thyroid, parietal cell, antimitochondrial antibodies or anti-DNA antibodies. The serum $\mathrm{C}_{3}$ at this time was normal $(150 \mathrm{mg} / 100 \mathrm{ml})$.

\section{Further treatment and progress}

One year later, apparently following the ingestion of gluten, weight loss and steatorrhoea recurred. In September 1967, she deteriorated rapidly with fatigue, further skin pigmentation, hypotension and vomiting, and she was admitted to St Luke's Hospital, Guildford, where a clinical examination revealed a pigmented, thin woman with marked hypotension (blood pressure 70/50). There was hyponatraemia (serum sodium $118 \mathrm{mN}$ ). The diagnosis of Addison's disease was confirmed by the rapid clinical response to saline infusions, prednisone $(10 \mathrm{mg} \mathrm{tds})$ and fluorocortisone $(0 \cdot 1 \mathrm{mg}$ bd) therapy. Two weeks later she was discharged from hospital feeling well. Following omission of her steroid therapy for 24 hours she became hypotensive and lapsed into coma. After resuscitation with parenteral hydrocortisone at St Luke's Hospital, she was transferred to the Hammersmith Hospital. Clinical examination now showed a thin, pigmented woman with an extensive rash involving the trunk and limbs. There was a patterned erythema, skin nodules and plaques and ulceration in some areas suggesting a lymphoma. Skin biopsy, however, showed the appearances of a severe vasculitis affecting mainly small dermal vessels with a heavy perivascular, mixed inflammatory cell infiltrate (Fig. 7). The diagnosis of Addison's disease was confirmed by the ACTH stimulation test. The very low 9 am pre-stimulation serum cortisol level of $5.5 \mu \mathrm{g} / 100 \mathrm{ml}$ rose to only $8.5 \mu \mathrm{g} / 100 \mathrm{ml}$ following five days' stimulation with ACTH gel (40 iu bd). Despite adequate steroid replacement therapy she remained unwell and was severely malnourished with fever and hypotension but there was no evidence of septicaemia. Doses of prednisone up to $80 \mathrm{mg} /$ day had no effect on the skin rash. A further sudden deterioration followed the perforation of a gastric ulcer. Now desperately ill and unfit for surgery, she was managed with an intensive conservative regime but progressively

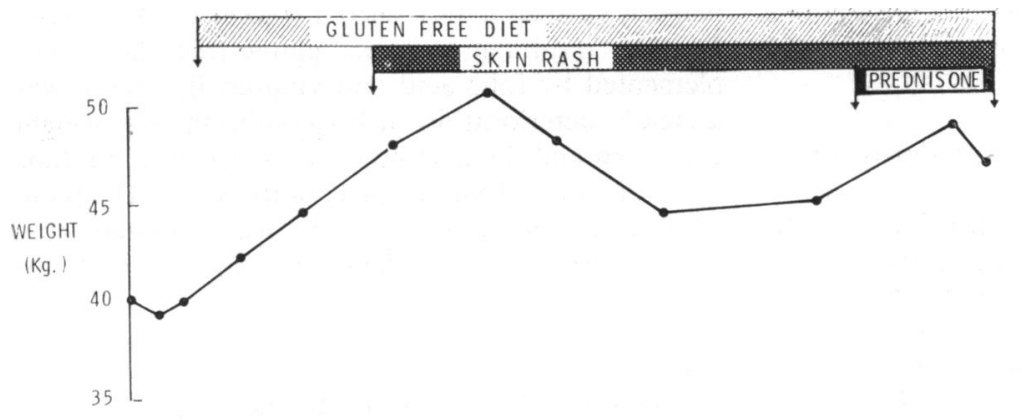

Fig. 6 Clinical course of case 3 , correlating weight, skin rash, faecal fat, and jejunal biopsy appearances with treatment.

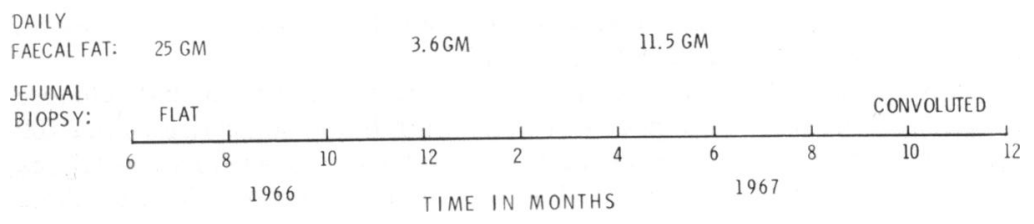




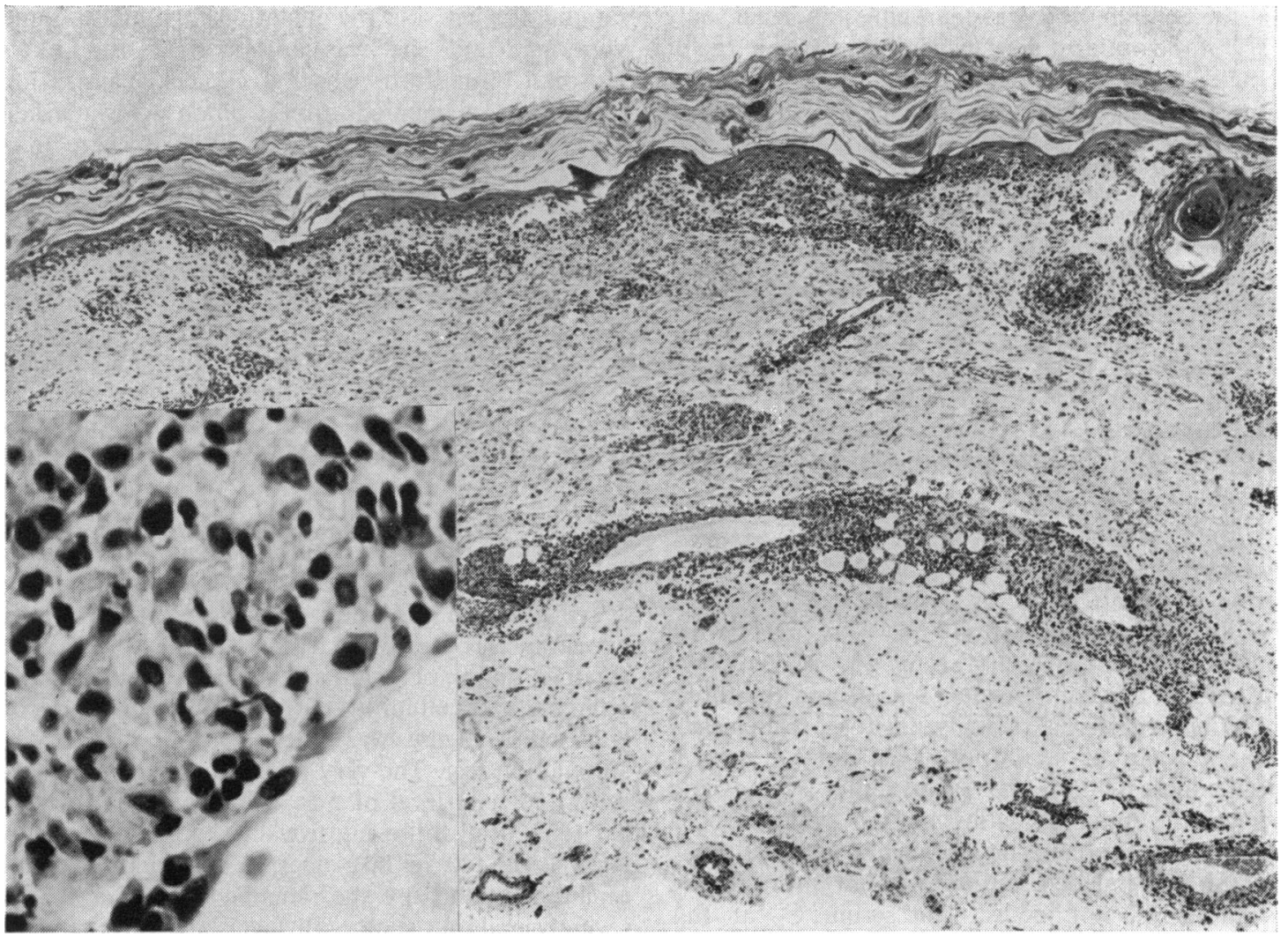

Fig. 7 Pronounced vasculitis in skin biopsy from case 3. The inflammatory cells are mixed in type and include lymphocytes and plasma cells as well as polymorphs. $H$ and $E \times 56$. Inset $H$ and $E \times 550$.

deteriorated until her death three days later. At necropsy, evidence of peritonitis, a perforated gastric ulcer, and coeliac and Addison's disease was present, but no sign of a lymphoma. Extensive tissue sections showed that the vasculitis was confined to dermal vessels.

CASE 4: ADULT COELIAC DISEASE, CRYOGLOBULINAEMIA, AND VASCULITIS

H.S. was aged 50 at the time of his death in 1967. In 1953, at the age of 36 , he first developed intermittent abdominal pain, weight loss, and diarrhoea. Investigations revealed megaloblastic anaemia (haemoglobin $7 \mathrm{~g} / 100 \mathrm{ml}$ ), folic acid deficiency (serum folate $1.5 \mathrm{ng} / \mathrm{ml}$ ), and steatorrhoea (faecal fat $14.3 \mathrm{~g} /$ day). The diagnosis of coeliac disease was supported by a marked clinical response to treatment with a strict gluten-free diet. Ten years later a jejunal biopsy was performed for the first time and showed partial villous atrophy (Fig. 8). He remained well on the diet with folic acid supplements until 1965 when he developed a gastric ulcer which was treated with the antacid Nulacin, a proprietary product which contains gluten. The gastric ulcer healed but the patient began to lose weight ( $7 \mathrm{~kg}$ in three months) and marked steatorrhoea recurred (faecal fat $15 \mathrm{~g} /$ day). Despite resuming a strict gluten-free diet, supplemented by folic acid and vitamin $\mathrm{B}_{12}$, there was a steady deterioration in his condition. His weight decreased and the diarrhoea became worse. In June 1966 he was admitted to Hammersmith Hospital. Clinical examination now revealed a wasted, thin man. There was no evidence of a skin rash at this time.

\section{Investigations}

Haemoglobin $13.2 \mathrm{~g} / 100 \mathrm{ml}$. Stained blood film was normal, serum $B_{12}(900 \mathrm{pg} / \mathrm{ml})$ and folate $(6.9$ $\mathrm{ng} / \mathrm{ml}$ ) were normal but there was a reduced serum iron $(80 \mu \mathrm{g} / 100 \mathrm{ml})$.

Intestinal function tests showed a flat glucose tolerance test (maximum blood sugar rise $10 \mathrm{mg} / 100$ $\mathrm{ml}$ in one and a half hours) and severe steatorrhoea

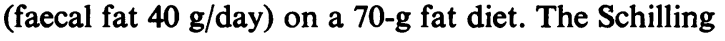




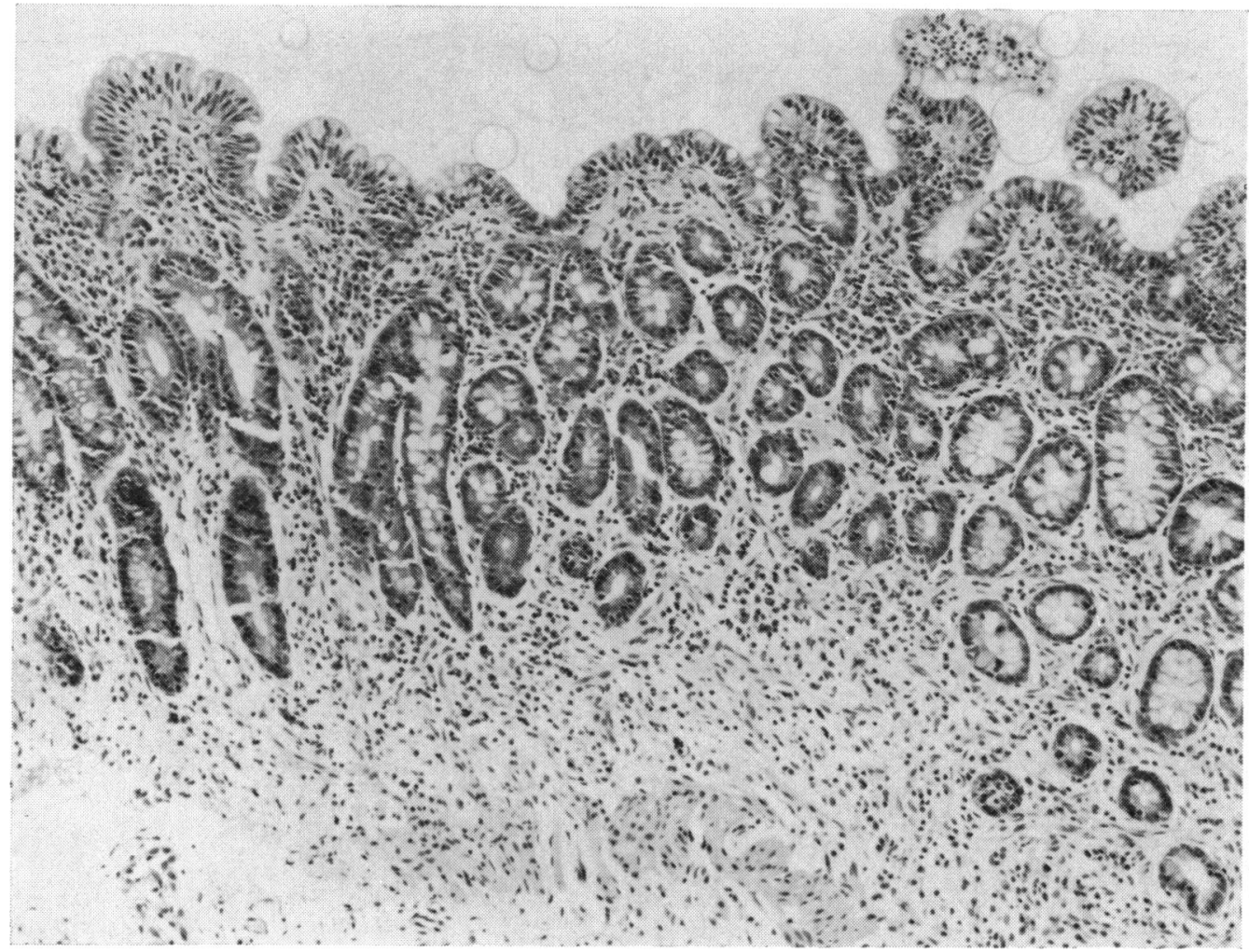

Fig. 8 Jejunal biopsy from case 4 after 10 years' treatment with a gluten-free diet, showing marked villous atrophy with occasional small stumpy villi. The surface cells are tall and columnar. $H$ and $E$ $\times 100$.

test was also abnormal, only $1.1 \%$ of the oral test dose given with intrinsic factor being excreted in 24 hours. The barium follow through showed a most unusual picture. The entire small intestine was abnormal with rigid tubular loops separated from each other by apparently thickened walls. The jejunal biopsy now showed a flat mucosal surface on dissecting microscopy and the appearances of subtotal villous atrophy on histological examination (Fig 9). The surface epithelium appeared badly damaged and there was a marked hyaline fibrosis in the subepithelial area.

\section{Treatment and progress}

Despite a diet strictly free of gluten and milk products, his condition continued to deteriorate. A laparotomy was performed to exclude intestinal lymphoma, but no abnormality was found apart from a very thin-walled intestine. No intestinal biopsy was taken. Subsequently, prednisone therapy and intensive intravenous feeding failed to improve his condition and he deteriorated further. He developed ulcers of the mouth, glossitis, hypoproteinaemia (serum albumin $1.7 \mathrm{~g} / 100 \mathrm{ml}$ ), and disordered liver function (serum isocitric dehydrogenase $25 \mathrm{iu} / 100$ $\mathrm{ml}$, bilirubin $1.4 \mathrm{mg} / 100 \mathrm{ml}$, alkaline phosphatase $25 \mathrm{KAU}$, bromsulphalein retention $20 \%$ ). Liver biopsy showed moderate fatty change with some parenchymal cell necrosis but no other abnormality.

In November 1966, while on prednisone therapy and a gluten-free diet, an erythematous, papular, scaly rash first appeared, affecting the limbs mainly (Fig. 10), and healing to leave flat pigmented areas. Skin biopsy showed an acute necrotising arteritis of dermal vessels with a heavy inflammatory cell infiltrate (Fig. 11).

\section{Immunological studies}

A mixed cryoglobulinaemia $(175 \mathrm{mg} / 100 \mathrm{ml})$, consisting of IgG $135 \mathrm{mg} / 100 \mathrm{ml}$ and IgM $40 \mathrm{mg} / 100$ $\mathrm{ml}$ components (Fig. 2), was found in serum taken after the onset of the skin rash. The electrophoretic strip of serum proteins showed an increase in the total globulin fraction $(3.8 \mathrm{~g} / 100 \mathrm{ml})$ but no evidence of a paraprotein band. The latex test was negative and the serum $\mathrm{C}_{3}$ level was normal $(128 \mathrm{mg} / 100 \mathrm{ml})$. 

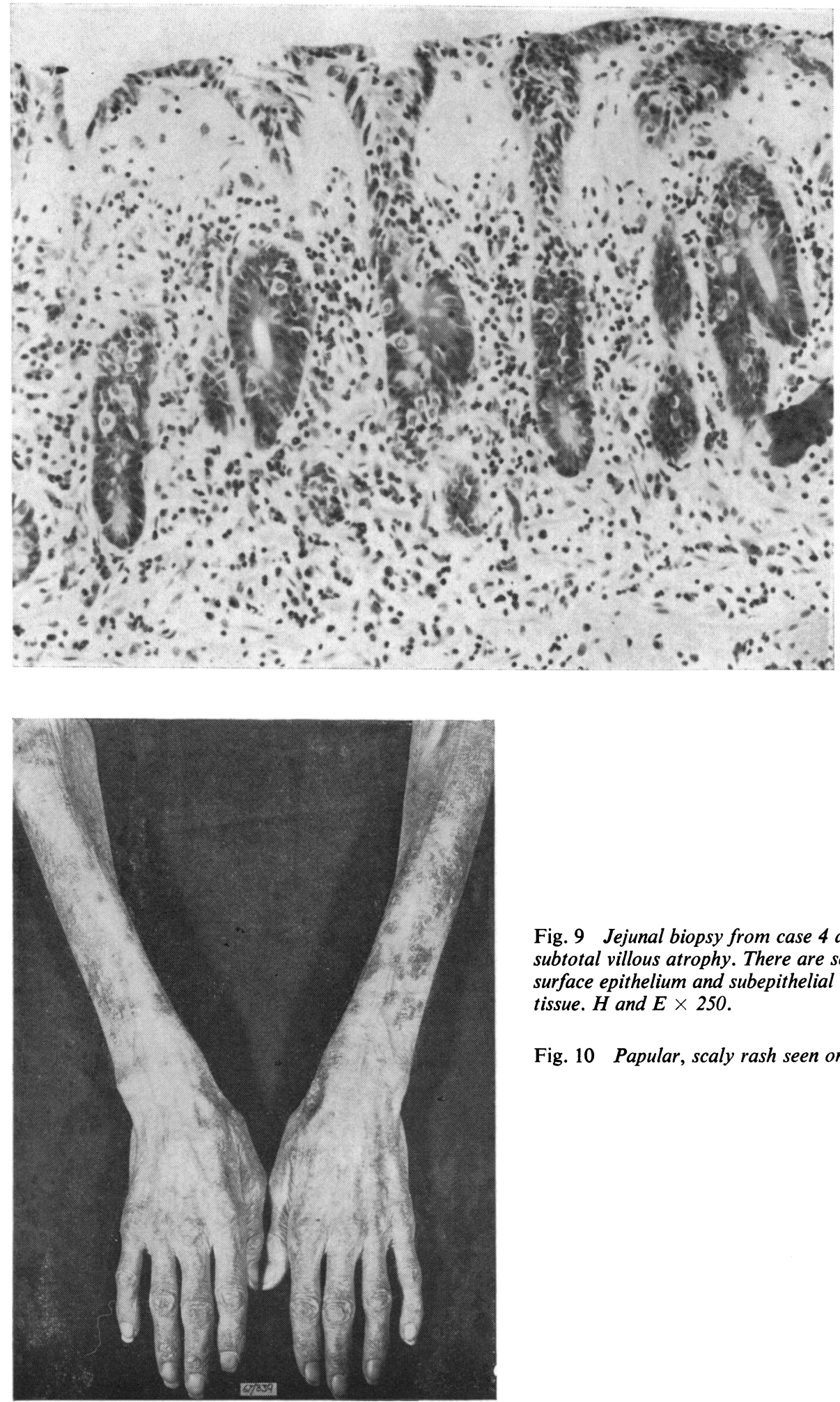

Fig. 9 Jejunal biopsy from case 4 after relapse, showing subtotal villous atrophy. There are severe changes in the surface epithelium and subepithelial hyaline fibrous tissue. $H$ and $E \times 250$.

Fig. 10 Papular, scaly rash seen on the arms of case 4. 


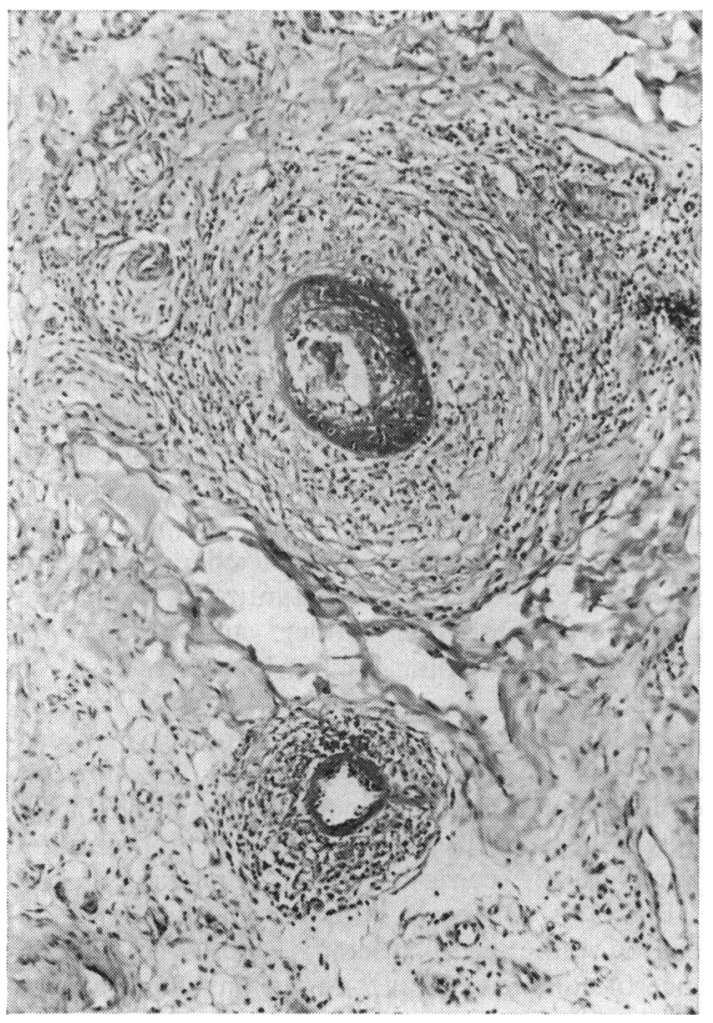

Fig. 11 Fibrinoid necrosis in small arteries in the dermis with associated perivascular inflammatory cells in skin biopsy taken from case 4. $H$ and $E \times 100$.

\section{Further treatment and progress}

Following prolonged intravenous feeding, further deterioration occurred culminating in death due to septicaemia and gross malnutrition. Postmortem examination showed subtotal villous atrophy of the jejunum with recent acute superficial ulceration and loss of mucosa. There was evidence of septicaemia with infective endocarditis and widespread abscesses. Extensive sections showed that the vasculitis was confined to the subdermal and larger muscle vessels.

\section{Discussion}

These four patients had malabsorption associated with a flat jejunal mucosa. It seems likely that all four were suffering from adult coeliac disease since they showed, at least initially, a satisfactory clinical response to withdrawal of gluten from the diet (Weinstein, Shimoda, Brow, and Rubin, 1970) and in two patients, improvement in the morphological appearances of the jejunal mucosa was shown. One patient (case 3 ) had a history suggesting mal- absorption which had dated from childhood. Two other patients (cases 1 and 2) remained in good health while receiving a strict gluten-free diet. The diagnosis in the fourth patient, however, is less certain. He originally presented with malabsorption and a severe megaloblastic anaemia at the age of 36 . He was treated with a strict gluten-free diet but a jejunal biopsy, first performed after 10 years of this treatment, showed partial villous atrophy (Fig. 8). Two years later, his condition relapsed with evidence of severe malabsorption and progressive inanition that led to his death. The jejunal mucosa was now completely flat, and beneath the enterocytes there was a thick layer of collagen (Fig. 9). The association of malabsorption, a flat jejunal mucosa, and collagen beneath the epithelial cells has previously been reported (Hourihane, 1963). Some authors consider this to represent a specific condition, collagenous sprue, possibly unrelated to coeliac disease (Weinstein, Saunders, Tytgat, and Rubin, 1970). Collagen in varying amounts, however, may be found beneath the enterocytes in jejunal biopsies obtained from patients with untreated coeliac disease, and in one study was present in $35 \%$ of biopsies from such patients (Hourihane, 1963). Furthermore, when coeliac children whose mucosa has returned to normal following successful treatment with a gluten-free diet are given a gluten challenge, one of the first abnormalities to be seen on electron microscopy is the accumulation of collagen beneath the basement membrane (Shmerling and Shiner, 1970). For these reasons the presence of collagen is not inconsistent with a diagnosis of coeliac disease, even though the patient ultimately fails to respond to a gluten-free diet. It seems likely that, although initially suffering from coeliac disease and responding to a gluten-free diet, his final illness may have represented an unusually severe reaction to the re-introduction of gluten.

The four patients all had vasculitis and cryoglobulinaemia. Three patients (cases 1, 3, and 4) had extensive skin rashes. In the first patient (case 1) the dermatological appearances were suggestive of cryoglobulinaemia although lesions were not provoked by exposure to cold but were precipitated by exercise (Bromberg-Szek and Müller, 1961) and were related to posture. In the other two patients (cases 3 and 4), the diagnosis of cryoglobulinaemia was not initially made and in both instances an underlying lymphoma was suspected. There were papular, blotchy, erythematous areas of the skin, which proceeded to ulceration in case 3 . Biopsies of the skin in both cases showed extensive vasculitis (Figs. 7 and 11). In case 3 the vasculitis at necropsy was confined to dermal vessels and in case 4 lesions were also seen in muscle vessels. In case 2 , who was 
also suffering from sarcoidosis, the dermatological lesion caused by vasculitis was erythema nodosum. However, vasculitis of the retinal veins and possibly the leg veins also occurred.

Cryoglobulins were found in the serum of all these four patients. In each case there was a mixed cryoglobulinaemia, the cryoglobulins being composed of immunoglobulins of more than one class. In three patients (cases 1,3 , and 4 ), the only components of the cryoglobulin were IgG and IgM, whilst in case 2 the cryoglobulin was formed of IgG, IgA, and IgM (Fig. 2).

Mixed cryoglobulinaemia has been reported in a variety of diseases, especially connective tissue disorders and certain viral and bacterial infections. It may also occur unassociated with any particular disease (Wager, Rosanen, Lassus, and Mustakallio, 1967; Meltzer, Franklin, Elias, McCluskey, and Cooper, 1966). Clinically, mixed cryoglobulinaemia may manifest with purpuric vasculitis, polyarthralgia, weakness, lymphadenopathy, and occasionally diffuse glomerulonephritis. Rheumatoid factor and autoantibodies are often present in the serum (Meltzer et al, 1966). Many of these features were found in the four patients discussed. Vasculitis was found in all four patients and was verified by skin biopsies in three patients (cases 1,3 , and 4), while Raynaud's phenomenon, lymphadenopathy, and polyarthralgia were additional findings in case 1 . In one patient (case 2) parietal cell and thyroid autoantibodies were present but in case 3, despite the presence of Addison's disease, no serum autoantibodies were found. Rheumatoid factor was found in the serum of two patients (cases 1 and 3). In case 2, the erythema nodosum was attributable to sarcoidosis. The subsequent retinal periphlebitis and thrombophlebitis are recognized features of cryoglobulinaemia, especially when associated with thrombosis of veins in other sites (Ritzmann and Levin, 1961) although this fundal appearance has also been reported in sarcoidosis (Kohner and Greenberg, 1964). In this case sarcoidosis, adult coeliac disease, and cryoglobulinaemia coexist. The association of sarcoidosis with monoclonal macrocryoglobulinaemia has been reported previously in one patient (Turkington and Buckley, 1966). In case 2 , therefore, it is not possible to state whether the cryoglobulinaemia is more significantly associated with coeliac disease or with sarcoidosis.

In case 1 , the purified cryoprecipitate was shown to consist of IgM and IgG components which, when separated into pure IgM and IgG fractions, lost their cryoprecipitability. Recombination of these frctions restored cryoprecipitability, strongly suggesting that the cryoglobulin consisted of an antigen antibody complex, a recognized property of mixed cryoglobulins (Wager et al, 1967; Zinneman, Levi, and Seal, 1968). Neither the IgM nor the IgG fraction from case 1 showed any antibody activity against alpha gliadin or crude gliadin, suggesting that the cryoglobulin complex was not directly related to humoral defence against antigens derived from gluten.

Serum levels of the $\mathrm{C}_{3}$ component of complement were normal in cases 1,3 , and 4, and raised in case 2. In two patients (cases 1 and 2), the total haemolytic complement levels in serum were normal, contrasting with the reduced total haemolytic complement levels reported by Reithmüller, Meltzer, Franklin, and Miescher (1966) in patients with mixed cryoglobulinaemia.

It has been suggested that mixed cryoglobulins represent circulating antigen-antibody complexes (Lospalluto, Dorward, Miller, and Ziff, 1962; Meltzer and Franklin, 1967) which may result in deposition of immune complexes in vessels, causing an immune complex disease. The finding of necrotizing vasculitis, heavy perivascular inflammatory cell infiltration, autoantibodies, rheumatoid factor, and the deposition of IgG, IgM, and fibrin around dermal vessels seen by immunofluorescence in case 1 (Fig. 5) is consistent with immune complex deposition initiating a vasculitis. However, the absence of complement in these lesions is at variance with this concept.

The occurrence of mixed cryoglobulinaemia and vasculitis in four adult coeliac patients suggests that these associations are immunologically significant and represent a further example of altered immunity in coeliac disease. It is suggested that coeliac disease, with its postulated dysgammaglobulinaemia (Hobbs, Hepner, Douglas, Crabbé, and Johansson, 1969), is associated with an increased incidence of altered immunity and that cryoglobulinaemia represents a further example of this.

We wish to thank Dr Karlish of Battle Hospital, Reading, for kindly allowing us to study case 2, which has been previously published as a case report associating sarcoidosis and coeliac disease (Smith and Karlish, 1966).

\section{References}

Booth, C. C. (1970). The enterocyte in coeliac disease. Brit. med. J., 4, 14-17.

Bromberg-Sznek, S., and Müller, J. (1961). Experiments on the mechanism of precipitation of cryoglobulins. Acta med. scand., $170,277-285$.

Hekkens, W. T. Haex, A. J., and Willighagen, R. G. (1970). Some aspects of gliadin fractionation and testing by a histochemical method. In Coeliac Disease, edited by C. C. Booth and R. H. Dowling. Churchill, Livingstone, London.

Hobbs, J. R., and Hepner, G. W. (1968). Deficiency of gamma M-globulins in coeliac disease. Lancet, 1, 217-220.

Hobbs, J. R., Hepner, G. W., Douglas, A. P., Crabbe, P. A., and 
Johansson, S. G. O. (1969). Immunological mystery of coeliac disease. Lancet, 2, 649-650.

Hourihane, D. O'B. (1963). The histology of intestinal biopsies. Proc. roy. Soc. Med., 56, 1073-1077.

Katz, J., Kantor, F. S., and Herskovic, T. (1968). Intestinal antibodies to wheat fractions in celiac disease. Ann. intern. Med., 69, 1149-1153.

Kohner, E., and Greenberg, G. (1964). Fundal lesions in sarcoidosis. Postgrad. med. J., 40, 717-719.

Laurell, C. B. (1965). Antigen antibody crossed electrophoresis. Analyt. Biochem., 10, 358-361.

Lospalluto, J., Dorward, B., Miller, W., Jr., and Ziff, M. (1962). Cryoglobulinemia based on interaction between a gamma macroglobulin and 7S gammaglobulin. Amer. J. Med., 32, 142147.

Mancini, G., Carbonara, A. O., and Heremans, J. F. (1965). Immunochemical quantitation of antigens by single radial immunodiffusion. Immunochemistry, 2, 235-254.

Mayer, M. M., Croft, C. C., and Gray, M. M. (1948). Kinetic studies on immune haemolysis. J. exp. Med., 88, 427-444.

Meltzer, M., and Franklin, E. C. (1967). Cryoglobulins, rheumatoid factors and connective tissue disorders. Arthr. and Rheum., $10,488-492$.

Meltzer, M., Franklin, E. C., Elias, K., McCluskey, R. T., and Cooper, N. (1966). Cryoglobulinemia-A clinical and laboratory study. Amer. J. Med., 40, 837-856.

Melvin, K. E. W., Hepner, G. W., Bordier, P., Neale, G., and Joplin, G. F. (1970). Calcium metabolism and bone pathology in adult coeliac disease. Quart. J. Med., 39, 83-113.

Ouchterlony, O. (1958). Diffusion-in-gel methods for immunological analysis. Progr. Allergy, 5, 1-78.

Reithmüller, G. Meltzer, M., Franklin, E., and Miescher, P. A. (1966). Serum complement levels in patients with mixed (IgM-IgG) cryoglobulinaemia. Clin. exp. Immunol., 1, 337-339.

Ritzmann, S. E., and Levin, W. C. (1961). Cryopathies: a review. Arch. Intern. Med., 107, 186-204.

Rose, H. M., Ragan, C., Pearce, E., and Lipman, M. O. (1948).
Differential agglutination of normal and sensitized sheep erythrocytes by sera of patients with rheumatoid arthritis. Proc. Soc. exp. Biol. (N.Y.), 68, 1-6.

Rubin, W., Fauci, A. S., Sleisenger, M. H., and Jeffries, G. H. (1965). Immunofluorescent studies in adult celiac disease. $J$. clin. Invest., 44, 475-485.

Shmerling, D. H., and Shiner, M. (1970). The response of the intestinal mucosa to the intraduodenal instillation of gluten in patients with coeliac disease during remission. In Coeliac Disease, 64-75, edited by C. C. Booth and R. H. Dowling, pp. 64-75. Churchill, Livingstone, London.

Singer, J. M., and Plotz, C. M. (1956). The latex fixation test. 1. Application to the serologic diagnosis of rheumatoid arthritis. Amer. J. Med., 21, 888-892.

Smith, B. D. O., and Karlish, A. J. (1966). Sarcoidosis with recurrent thrombophlebitis and idiopathic steatorrhoea. Proc. roy. Soc. Med., 59, 569-570.

Soltoft, J. (1970). Immunoglobulin-containing cells in non-tropical sprue. Clin. exp. Immunol., 6, 413-420.

Taylor, K. B., Truelove, S. C., Thomson, D. L., and Wright, R. (1961). An immunological study of coeliac disease and idiopathic steatorrhoea: serological reactions to gluten and milk products. Brit. med. J., 2, 1727-1731.

Turkington, R. W., and Buckley, C. E. (1966). Macrocryoglobulinaemia and sarcoidosis. Amer. J. Med., 40, 156-164.

Wager, O., Rasanen, J. A., Lassus, A., and Mustakallio, K. K. (1967). Mixed cryoimmunoglobulins. Acta path. microbiol. scand., 69, 610-611.

Weinstein, W. M., Shimoda, S. S., Brow, J. R., and Rubin, C. F. (1970). What is coeliac sprue? In Coeliac Disease, edited by C. C. Booth and R. H. Dowling, pp. 232-245. Churchill, Livingstone, London.

Weinstein, W. M., Saunders, D. R., Tytgat, G. N., and Rubin, C. E. (1970). Collagenous sprue-an unrecognised type of malabsorption. New Engl. J. Med., 283, 1297-1301.

Zinneman, H. H., Levi, D., and Seal, U. S. (1968). On the nature of cryoglobulins. J. Immunol., 100, 594-603. 